\title{
Struktur Morfologi Batang Tumbuhan di Taman Wisata Alam Punti Kayu Palembang
}

\author{
Dewi Rosanti \\ e-mail:dwrosanti@gmail.com \\ Program Studi Biologi, Fakultas MIPA, Universitas PGRI Palembang
}

\begin{abstract}
Research on the morphological structure of stems to the vegetation found in the Taman Punti Kayu Palembang Tourism Park has been conducted in February to March 2017. This study aims to study the types of morphology of stems, including the type of stem, branching and the direction of growing branches. Results of the study found 22 species of tree vegetation from 16 families. The result of morphological analysis of 22 species stems that it is concluded that the type of stem owned is woody stem (lignosus) and grass (calmus), the type of branching is monopodial and simpodial and the direction of branch growth is orthotropic and plagiatropic.
\end{abstract}

Keywords : caulis, monopodial, sympodial, ortotropic, plagiotropic

\begin{abstract}
ABSTRAK
Penelitian tentang struktur morfologi batang terhadap vegetasi yang terdapat di kawasan Taman Wisata Punti Kayu Palembang telah dilakukan pada bulan Februari sampai Maret 2017. Penelitian ini bertujuan mengkaji tipe-tipe morfologi batang, meliputi jenis batang, percabangan dan arah tumbuh cabang. Hasil penelitian ditemukan 22 species vegetasi pohon dari 16 familia. Hasil analisis morfologi batang 22 species tersebut disimpulkan bahwa jenis batang yang dimiliki adalah batang berkayu (lignosus) dan rumput (calmus), tipe percabangan bersifat monopodial dan simpodial dan arah pertumbuhan cabang bersifat ortotropik dan plagiatropik.
\end{abstract}

Kata kunci : caulis, monopodial, simpodial, ortotropik, plagiotropik

\section{PENDAHULUAN}

Taman Wisata Alam (TWA) Punti Kayu merupakan salah satu hutan kota yang dibangun di Kota Palembang dan berfungsi sebagai paru-paru kota. Vegetasi di Taman Wisata Alam Punti Kayu didominasi oleh tusam (Pinus merkusii), selain itu terdapat jenis-jenis lain seperti akasia (Acacia mangium), albasia (Albazia falcatari), ampupu (Eucalyptus alba), bambu (Bambusa spp), kayu putih (Malaleuca leucadendron), mahoni (Swietenia magahoni), pulai (Alstonia granensis) dan sengon (Alstonia granensis).
Hutan Punti Kayu dijadikan sebagai hutan percobaan pinus melalui Surat Keputusan (SK) Menhut No. 57/KptsII/1985 tanggal 7 April 1985 yang kemudian diubah fungsinya menjadi hutan wisata. Hutan wisata Punti Kayu ditunjuk sebagai Taman Wisata Alam (TWA) melalui SK. Menhut No 76/KptsII/ 2001 tanggal 15 Maret 2001 dengan luas 50 ha dan ditetapkan sebagai TWA melalui SK Menteri Kehutanan Nomor 9273/Kpts-II/2002 dengan luas 50 ha (Syabana et al., 2015).

Keanekaragaman hayati tumbuhan di TWA Punti Kayu dapat ditinjau dari tingkat pertumbuhan vegetasi. Vegetasi- 
vegetasi ini banyak dimanfaatkan oleh salah satu satwa kera ekor panjang (Macaca fascicularis) untuk aktivitas sehari-hari seperti bermain dan makan, karena jenis satwa ini dibiarkan hidup bebas oleh pengelola Taman Wisata Alam Punti Kayu dan dianggap tidak mengganggu aktivitas pengunjung (Qurniati dan Saleh, 2010; Endarwati, 2005 dalam Sutoyo, 2010).

Keanekaragaman tumbuhan dapat ditinjau dari struktur morfologinya, baik daun, batang, akar, bunga, dan organ modifikasi (Rosanti, 2013). Morfologi batang untuk vegetasi tingkat pohon dapat menjadi karakteristik arsitektur pohon, mulai dari pola pertumbuhan batang, cabang, dan ranting yang berbeda-beda. Hal ini dapat diartikan bahwa pohon-pohon tersebut memiliki model arsitektur pohon tertentu. Arsitektur pohon merupakan gambaran morfologi batang pada suatu fase tertentu pertumbuhan batang. (Hidayat, 1992 dalam Hasanuddin, 2013; Jumingin et al., 2016).

Menurut Tjitrosoepomo (2010) dan Rosanti (2013) batang merupakan bagian tubuh tumbuhan yang amat penting, dan mengingat tempat serta kedudukan batang bagi tubuh tumbuhan, batang dapat disamakan dengan sumbu tubuh tumbuhan. Pertumbuhan batang dapat dilihat dari percabangannya, kebanyakan tumbuhan melakukan percabang walaupun sedikit. Pada dasarnya, morfologi batang pada tingkat pertumbuhan batang pokok inilah yang akan menjadi arsitektur tumbuhan.

Setiap jenis pohon memiliki ciri yang khas dalam rangkaian proses pertumbuhannya yang diwariskan secara genetik pada keturunannya, termasuk dari morfologi batangnya, akan menjadi sifat taksonomik. Oleh karena sifatnya yang konsisten maka model arsitektur pada setiap jenis pohon dapat dijadikan data tambahan dalam membedakannya dengan jenis pohon lain (Arrijani, 2006).

\section{BAHAN DAN METODE}

Penelitian ini telah dilakukan dari bulan Februari sampai bulan Maret 2017, bertempat di Taman Wisata Alam Punti Kayu Kota Palembang Provinsi Sumatera Selatan. menggunakan metode jelajah (survey) dan pengamatan langsung terhadap model arsitektur pohon secara purpsosive sampling, dengan menentukan sampel yang akan diteliti, yaitu vegetasi tumbuhan untuk tingkat pohon yang ada di Taman Wisata Alam Punti Kayu Kota Palembang Provinsi Sumatera Selatan (Indriyanto, 2006).

Setiap sampel difoto dan dideskripsikan struktur morfologi batang melitupi batang pokok dan jenis percabangannya. Pengamatan lapangan dilaksanakan dengan cara melakukan pengamatan langsung terhadap obyek kajian di lapangan atau di lokasi penelitian, jika pada area B terdapat pohon yang sama dan sudah diamati pada area A maka pengamatan tidak diulang untuk kedua kalinya.

\section{HASIL DAN PEMBAHASAN}

Berdasarkan hasil penelitian dapat diketahui bahwa terdapat beragam tipe morfologi batang yang ada di Taman Wisata Alam Punti Kayu. 
Tabel 1. Tipe Morfologi Batang di Taman Wisata Alam Punti Kayu Palembang.

\begin{tabular}{|c|c|c|c|c|c|}
\hline No. & Familia & Nama Ilmiah & $\begin{array}{c}\text { Nama } \\
\text { Daerah }\end{array}$ & Percabangan & $\begin{array}{c}\text { Pertumbuhan } \\
\text { cabang }\end{array}$ \\
\hline \multirow[t]{5}{*}{1.} & Fabaceae & Acacia mangium & Akasia & Monopodial & Ortotropik \\
\hline & & Tamarindus indica & Asam jawa & Monopodial & Ortotropik \\
\hline & & $\begin{array}{l}\text { Pterocarpus } \\
\text { indicus }\end{array}$ & Angsana & Monopodial & Ortotropik \\
\hline & & $\begin{array}{l}\text { Archidendron } \\
\text { pauciflorum }\end{array}$ & Jengkol & Monopodial & Ortotropik \\
\hline & & Albizia chinensis & Sengon & Monopodial & Ortotropik \\
\hline 2. & Euphorbiaceae & Ricinus communis & Jarak & Monopodial & Ortotropik \\
\hline 3. & Combretaceae & $\begin{array}{l}\text { Terminalia } \\
\text { cattapa }\end{array}$ & Ketapang & Monopodial & Ortotropik \\
\hline 4. & Myrtaceae & Syzygium aqueum & Jambu air & Monopodial & Ortotropik \\
\hline 5. & Anacardiaceae & Mangifera indica & Mangga & Monopodial & Ortotropik \\
\hline 6. & Sapindaceae & $\begin{array}{l}\text { Filicium decipiens } \\
\text { Pometia pinnata }\end{array}$ & $\begin{array}{l}\text { Krey payung } \\
\text { Matoa }\end{array}$ & $\begin{array}{l}\text { Monopodial } \\
\text { Monopodial }\end{array}$ & $\begin{array}{l}\text { Ortotropik } \\
\text { Ortotropik }\end{array}$ \\
\hline \multirow[t]{4}{*}{10.} & Palmae & Areca catechu & Pinang & Monopodial & - \\
\hline & & Cocos nucifera & Kelapa & Monopodial & - \\
\hline & & Roystonea regia & Palem Raja & Monopodial & - \\
\hline & & Elaeis guineensis & Kelapa Sawit & Monopodial & - \\
\hline \multirow[t]{2}{*}{11.} & Graminae & $\begin{array}{l}\text { Thyrsostachys } \\
\text { siamensis }\end{array}$ & Bambu Siam & Monopodial & - \\
\hline & & Bambusa vulgaris & $\begin{array}{l}\text { Bambu } \\
\text { Kuning }\end{array}$ & Monopodial & - \\
\hline 12. & Annonaceae & $\begin{array}{l}\text { Polyalthia } \\
\text { longifolia }\end{array}$ & Gelondokan & Monopodial & Plagiotropik \\
\hline 13. & Pinnaceae & Pinus merkusii & Pinus & Monopodial & Ortotropik \\
\hline 14. & Lamiaceae & Tectona grandis & Jati & Monopodial & Ortotropik \\
\hline 15. & Lauraceae & $\begin{array}{l}\text { Phoebe } \\
\text { hunanensis }\end{array}$ & Medang & Monopodial & Plagiotropik \\
\hline 16. & Verbenaceae & $\begin{array}{l}\text { Peronema } \\
\text { canescens }\end{array}$ & Sungkai & Monopodial & Plagiotropik \\
\hline
\end{tabular}

Dari 16 species yang diteliti, bila ditinjau dari jenis batangnya terdapat 2 karakteristik yaitu batang berkayu (familia Fabaceae, Euphorbiaceae, Combretaceae, Myrtaceae, Anacardiaceae, Sapindaceae, Meliaceae, Sapotaceae, Apocinaceae, Annonaceae,
Pinnaceae, Lamiaceae, Lauraceae dan Verbenaceae) dan batang rumput (familia Palmae dan Graminae). Batang berkayu (lignosus) dimiliki tumbuhan dari Class Dicotyledoneae. Batang berkayu juga terbagi menjadi dua tipe yaitu semak (frutices) dan pohon (arbores). Tipe 
semak dimiliki tumbuhan yang pada pertumbuhannya tidak mencapai diameter batang lebih dari $10 \mathrm{~cm}$. Sedangkan pohon dimiliki tumbuhan yang diameter batangnya lebih $10 \mathrm{~cm}$ bahkan hingga lebih dari 1 meter.

Tipe percabangan hampir semua species memiliki batang pokok yang jelas dapat dibedakan dengan cabang, sehingga bertipe monopodial, kecuali Chrysophyllum cainito bertipe simpodial, karena batang pokok sulit dibedakan dengan cabang. Percabangan batang dapat ditentukan dengan cara melihat posisi batang pokok terhadap cabangnya. Bila batang pokok selalu terlihat jelas dibandingkan cabang-cabangnya maka disebut percabangan monopodial. Sedangkan bila batang pokok tidak dapat dibedakan dengan cabang, maka disebut percabangan simpodial. Umumnya tumbuhan memiliki percabangan monopodial (Rosanti, 2013).

Pertumbuhan cabang bersifat ortotropik (pertumbuhan ke atas) yaitu dari familia Fabaceae, Euphorbiaceae, Combretaceae, Myrtaceae, Anacardiaceae, Sapindaceae, Meliaceae, Sapotaceae, Apocinaceae, Pinnaceae, dan Lamiaceae. Familia Annonaceae, Lauraceae dan Verbenaceae memiliki pertumbuhan cabang bersifat plagiotropik (menuju ke samping atau terkulai ke bawah).

Familia Graminae dan Palmae tidak memiliki sifat pertumbuhan cabang, karena kedua familia ini termasuk Class Monocotyledoneae yang tidak memiliki percabangan. Menurut Rosanti (2016) dan Rosanti (2014), tumbuhan Graminae termasuk berbatang rumput dengan ruas yang banyak, sehingga tidak memiliki percabangan.

\section{KESIMPULAN}

Vegetasi tingkat pohon di Taman Wisata Alam Punti Kayu memiliki tipe morfologi batang berkayu (lignosus) dan rumput (calmus), tipe percabangan bersifat monopodial dan simpodial dan arah pertumbuhan cabang bersifat ortotropik dan plagiatropik.

\section{DAFTAR PUSTAKA}

Arrijani, 2006. Model arsitektur pohon pada Hulu DAS Cianjur Zona SubMontana Taman Nasional gunung Gede Pangrango. Jurnal Matematika, Sains, dan Teknologi 7(2):71-84. http://jurnal.ut.ac.id.

Hasanuddin. 2013. Model Arsitektur Pohon Hutan Kota Banda Aceh Sebagai Penunjang Praktikum Morfologi Tumbuhan. Jurnal EduBio Tropika 1(1):1-60. http://jurnal.unsyiah.ac.id.

Indriyanto. 2006. Ekologi Hutan. Jakarta: Penerbit PT Bumi Aksara.

Jumingin, Z. Dahlan, dan D. Setiabudidaya. 2016. Effect of Architectural Tree Model to the Noise Level of Motor Vehicle on Demang Lebar Daun Street Palembang. Biovalentia : Biological Research Journal 2(2):71-78.

http://biovalentia.mipa.unsri.ac.id

Qurniati. R., dan A. R. Saleh. 2010. Biaya Perjalanan Domestik Pengunjung Terhadap Manfaat Rekreasi di Taman Wisata Alam Punti Kayu (TWAPK) Kota Palembang. Jurnal Ilmu Pertanian Indonesia 15(2):83-87. http://journal.ipb.ac.id.

Rosanti, D. (2014). Taksonomi Tumbuhan Obat di Desa Riang Bandung Kecamatan Madang Suku Dua Oku Timur. Sainmatika: Jurnal Ilmiah Matematika dan Ilmu Pengetahuan Alam 11 (1): 42-49 
http://e-jurnal.univpgri-

palembang.ac.id/e_jurnal/index.php

/sainmatika/article/view/416

Rosanti, D. 2013. Morfologi Tumbuhan. Jakarta: Erlangga

Rosanti, D. (2016). Taksonomi Gulma Padi (Oryza Sativa) di Areal Persawahan Jakabaring Palembang. Sainmatika: Jurnal Ilmiah Matematika dan Ilmu Pengetahuan Alam 13 (1): 46-51. http://e-jurnal.univpgripalembang.ac.id/e_jurnal/index.php /sainmatika/article/view/990

Sutoyo. 2010. Keanekaragaman Hayati Indonesia. Buana Sains 10 (2):101106. http://jurnal.unitri.ac.id.

Syabana. T. A. A., S. Mareti., dan A. Kunarso. 2015. Potensi Karbon di Taman Wisata Alam Punti Kayu. Balai Konsevasi Sumber Daya Alam Sumatera Selatan. Palembang.

Tjitrosoepomo, G. 2010. Morfologi Tumbuhan. Yogyakarta: UGM Gadjah Mada University Press. 